\title{
More strings for British research
}

The British research enterprise has escaped yet another radical reorganization, that which would have been entailed in the creation of a single research council. But it may yet be sorry.

Demoralized British researchers at academic and cognate institutions have been surprisingly indifferent to the scheme, advocated last year by a committee under $\mathrm{Mr}$ J.R.S. Morris, that the five existing research councils should be rolled together. It is as if, like punchdrunk prizefighters, they have become self-preoccupied with pain, but uncaring about its source. Yet the issue is important if the enterprise is ever to recover from the past two decades of mismanagement and deprivation. And now, in any case, the issue has been settled (see page 294). The British government has set its face against upheaval, but will instead expect a reconstituted (and smaller) Advisory Board for the Research Councils (ABRC) to intervene more directly than has been its habit in the affairs of the research councils.

The obvious benefit of this decision is that another major upheaval will be avoided. That is something genuinely to be grateful for. Particular research councils, understandably jealous of the remnants of their autonomy, will also be at first relieved. For a while, at least, they can hope that the future will be an extrapolation of the past. And is it not true that the occasion of the Morris recommendations, principally the turf battle between the Medical Research Council and the Science and Engineering Research Council over the right to support nonmedical biology and its applications, could be settled without the need for legislation, with all the hostages to fortune that would create? The British government similarly has reasons to welcome the quiet life, with the uncertain prospect of a general election just two years ahead.

But the new arrangement could prove to be less palatable than it now appears. Everything will hang on how ABRC sets about its larger task. In principle, the research council system has two functions - to support basic research in academic institutions and to carry out what is fashionably called strategic research of relevance in designated fields such as agriculture, medicine and the natural environment. Within living memory, in 1971, the then government (of the same stripe as the present) enthusiastically endorsed Lord Rothschild's notion that government departments should stand proxy for the ultimate taxpayer beneficiaries of strategic research, but the departments have consistently ducked their responsibilities, notably in agriculture. The research councils have not been able so lightly to shrug off their responsibilities. They have commitments to research institutes and their staffs, while increasing proportions of what they spend are earmarked for particular fields of research.

The outstanding advantage of a unified research council is that it could have moulded its policies to a reappraisal of what is now the British national interest. Two objectives are conspicuous and generally agreed. First, Britain is heading for a shortage of technical skill that will be avoided only by the generous and ample support of graduate students and postdoctoral fellows. That requires that dignity should be restored to the research profession, whose penury has been too well advertised in the past decade. Second, the foundations of a healthy research community need to be rebuilt, in the hope that the British enterprise can recover some of its old sparkle. That requires that the research councils should spend a much larger proportion of their funds (nearly $£ 900$ million a year) on research projects conceived of by their clients, not themselves. There should be a third objective, less widely appreciated, that the shocking neglect of the social sciences in the past few years is made good.

Quite how even a streamlined ABRC can tackle these problems is far from clear. The council will remain advisory to the Department of Education and Science, not to the government as a whole. (The newest version of a central advisory body, the Advisory Council on Science and Technology, seems even less active than its predecessor, despite having the prime minister as chairman). It will have no executive authority, with the result that it will be able to persuade research councils to change their ways only by threatening that their annual budgets will be accompanied by explicit instructions from above, which will further demean the system as a whole while sanctifying the practice of earmarking research funds for particular projects.

The most serious danger in the new arrangements is that the link between the research community and its ultimate managers, one of the few sources of hope in a devastating decade, will be further attenuated. The other is that the whims of politicians, for projects as different as information technology and research in and around the Falklands Islands, will come to dominate British researchers' working lives. The new ABRC will need guile as well as courage to improve and not to worsen Britain's prospects in research. All that should matter now is that people's morale should be restored by a sense that their own good ideas can be prosecuted successfully. 